\title{
PENGEMBANGAN MODUL MATA PELAARAN AKUNTANSI KEUANGAN KOMPETENSI DASAR PERSEDIAAN BARANG DAGANGAN PADA SISWA KELAS XI AKUNTANSI DI SMK NEGERI 1 JEMBER SEMESTER GENAP TAHUN AJARAN 2017/2018
}

\author{
Shelvy Putri Astuti ${ }^{1}$, Titin Kartini ${ }^{1}$, Sutrisno Djaja ${ }^{1}$ \\ ${ }^{1}$ Program Studi Pendidikan Ekonomi, Fakultas Keguruan dan Ilmu Pendidikan, Universitas Jember \\ e-mail: titin_kartini8090@yahoo.com
}

\begin{abstract}
Abstrak
Penelitian pengembangan ini bertujuan untuk menghasilkan produk berupa modul akuntansi yang menarik, efisien, dan efektif pada mata pelajaran akuntansi keuangan kompetensi dasar persediaan barang dagangan untuk siswa kelas XI Akuntansi di SMK Negeri 1 Jember. Modul akuntansi ini dikembangkan menggunakan model pengembangan oleh Thiagarajan et al. Kelayakan modul dinilai melalui tahap validasi yang terdiri dari 3 aspek, yaitu validasi isi/materi, desain, dan bahasa. Validasi modul menghasilkan skor akhir masing-masing aspek yaitu 95,3\% untuk kelayakan isi/materi, 92,1\% untuk kelayakan desain, dan 95,5\% untuk kelayakan bahasa. Proses uji coba produk dilakukan sebanyak 2 kali, yaitu uji kelompok kecil dan uji kelompok besar. Uji kelompok kecil dilakukan pada 12 siswa kelas XI Akuntansi 1 dan uji kelompok besar dilakukan pada seluruh siswa kelas XI Akuntansi 3 yang berjumlah 38 siswa. Metode pengumpulan data yang digunakan adalah angket, tes, observasi, wawancara, dan dokumen. Teknik analisis data yang digunakan adalah uji tingkat daya tarik modul, uji tingkat efisiensi modul, dan uji tingkat efektivitas modul. Hasil uji tingkat daya tarik modul pada uji kelompok kecil adalah 86\% (sangat menarik) dengan waktu pembelajaran 3x3JP (lebih singkat dari alokasi waktu pada silabus) dan rata-rata hasil belajar meningkat ditunjukkan dengan hasil pretest 76,83 meningkat menjadi 85,17. Pada uji kelompok besar, uji tingkat daya tarik modul memperoleh rata-rata skor $91 \%$ (sangat menarik) dengan alokasi waktu pembelajaran 3x3JP, rata-rata nilai prestest yaitu 75,71 meningkat menjadi 85,13 pada rata-rata nilai posttest. Hasil uji coba tersebut menunjukkan bahwa modul akuntansi yang dikembangkan menarik, efisien, dan efektif.
\end{abstract}

Kata Kunci: Modul Akuntansi, Menarik, Efisien, Efektif, Persediaan Barang Dagangan

\section{PENDAHULUAN}

Bahan ajar menjadi faktor penting dalam proses pembelajaran, utamanya pada mata pelajaran akuntansi yang bersifat aplikatif. Bahan ajar di SMK Negeri 1 Jember untuk mata pelajaran Akuntansi Keuangan berupa buku teks akuntansi bersifat umum, terlalu ringkas, dan masih belum disertai dengan LKS (Lembar Kerja Siswa). Siswa kurang berminat untuk membaca, sehingga berpengaruh pada pemahaman siswa yang harus diberikan penjelasan secara berulang oleh guru. Oleh karena itu diperlukan pengembangan bahan ajar berupa modul yang lebih menarik, efisien, dan efektif pada mata pelajaran akuntansi keuangan kompetensi dasar persediaan barang dagangan untuk siswa kelas XI Akuntansi di SMK Negeri 1 Jember.

Modul merupakan salah satu satuan perangkat terkecil yang disusun secara sistematis, menyajikan seperangkat pengalaman belajar yang terencana dan didesain untuk membantu siswa dalam mencapai tujuan belajar yang ditentukan (Daryanto, 2013:9). Modul yang baik dan menarik yaitu modul yang memenuhi lima karakteristik, yaitu self intruction, self contained, stand alone, adaptif, dan user friendly. Penyusunan modul yang baik akan mengoptimalkan fungsi modul, diantaranya modul dapat menjadi bahan ajar yang mandiri, dapat membantu fungsi pendidik, sebagai alat evaluasi, dan sebagai bahan rujukan bagi siswa.

Modul akuntansi yang dihasilkan dalam pengembangan ini, yaitu modul yang menarik, efisien, dan efektif dalam proses pembelajaran. Modul dikatakan menarik apabila menimbulkan minat siswa untuk belajar. Minat siswa besar pengaruhnya terhadap belajar, karena bila bahan pelajaran yang dipelajari tidak sesuai dengan minat siswa, siswa tidak akan belajar dengan sebaik-baiknya, karena tidak ada daya tarik baginya (Slameto, 2015:57). Modul yang menarik ditunjukkan melalui menariknya desain sampul, layout isi materi, dan pengemasan tugas pada modul. Modul yang menarik akan memudahkan siswa untuk memahami isi/materi yang diajarkan, sehingga penggunaan modul juga dapat meningkatkan efisiensi proses pembelajaran. Efisiensi pembelajaran biasanya diukur dengan rasio antara keefektifan dan jumlah waktu yang dipakai siswa (Uno, 2008:21). Efisiensi penggunaan modul dapat dilihat dari jumlah alokasi waktu yang digunakan sesuai atau lebih 
singkat dari alokasi waktu yang tercantum pada silabus. Selanjutnya modul dapat dikatakan efektif apabila siswa mencapai ketuntasan belajar yang ditentukan (Muhafid, 2013). Tingkat pencapaian ketuntasan berupa peningkatan pengetahuan dan keterampilan serta pengembangan sikap siswa melalui proses pembelajaran. Efektivitas modul dapat ditunjukkan dari adanya peningkatan hasil belajar siswa sebelum dan sesudah menggunakan modul yang dikembangkan.Pentingnya pengembangan ini juga didasarkan pada mata pelajaran akuntansi keuangan kompetensi dasar persediaan barang dagangan mempunyai banyak metode dalam pencatatannya sehingga membuat siswa kesulitan untuk membandingkan dan menerapkan konsep perhitungan berbagai metode persediaan barang dagangan yang telah dipelajari ketika mengerjakan variasi soal lain. Siswa membutuhkan modul yang lebih rinci, memudahkan pemahaman siswa, menimbulkan daya tarik siswa, lebih efisien waktu dan meningkatkan hasil belajar. Modul akuntansi ini dilengkapi dengan kolom catatan, infografis yang berisi informasi seputar persediaan barang dagangan, terdapat LKS (Lembar Kerja Siswa), serta disusun dengan desain yang menarik sehingga memudahkan pemahaman siswa dan dapat menghemat waktu belajar siswa.

Berdasarkan pemaparan di atas, tujuan penelitian ini yaitu menghasilkan modul akuntansi yang menarik, efisien, dan efektif pada kompetensi dasar persediaan barang dagangan untuk siswa kelas XI Akuntansi di SMK Negeri 1 Jember.

\section{METODE}

Penelitian ini bertujuan menghasilkan produk berupa modul akuntansi keuangan KD persediaan barang dagangan untuk kelas XI Akuntansi dmi SMKNegeri 1 Jember yang menarik, efisien, dan efektif sesuai dengan kebutuhan dan karakteristik siswa. Model pengembangan yang digunakan dalam penelitian ini mengikuti alur dari Sivasailam Thiagarajan, Dorothy S. Semmel, dan Melvyn I. Semmel, yaitu model 4-D. Model 4D memiliki empat tahap pengembangan yaitu define (pendefinisian), design (perancangan), develope (pengembangan), disseminate (penyebaran). Model 4D lebih sesuai digunakan dalam penelitian pengembangan modul sebagai salah satu bentuk perangkat pembelajaran. Hal tersebut sesuai dengan pernyataan berikut “...Four-D model (define, design, develope, and disseminate) to be used for developing instructional materials for training teachers..." (Thiagarajan et al, 1974:1). Namun, peneliti hanya melakukan hingga tahap pengembangan, sehingga tidak ada kegiatan penyebaran kepada pengguna yang lebih luas. Tahap penyebaran tidak dilakukan dalam penelitian pengembangan ini karena modul yang dikembangkan belum tentu sesuai dengan kebutuhan dan karakteristik siswa pada sekolah menengah atas lainnya.

Subjek dari penelitian adalah sasaran uji coba dan validator produk. Subjek sasaran uji coba sebagai berikut, uji coba kelompok kecil: 12 peserta didik kelas XI Akuntansi 1 di SMK Negeri 1 Jember yang memiliki kemampuan heterogen dan uji coba kelompok besar: seluruh siswa kelas XI Akuntansi 3 yang terdiri dari 38 siswa. Validator is/materi modul, validator desain modul, dan validator bahasa adalah satu guru akuntansi, satu guru multimedia, dan satu guru mata pelajaran Bahasa Indonesia di SMK Negeri 1 Jember.

Analisis data daya tarik modul akuntansi dilakukan dengan menghitung persentase tingkat kemenarikan dari data angket yang didapat. Uji efisiensi dilakukan dengan membandingkan waktu yang digunakan dalam proses pembelajaran menggunakan modul akuntansi dengan alokasi waktu yang tersedia dalam silabus dan diperkuat dengan wawancara. Uji tingkat efektivitas dilakukan perbandingan rata-rata nilai sebelum (pretest) dan sesudah (posttest) penggunaan modul akuntansi.

\section{HASIL DAN PEMBAHASAN}

Hasil pengembangan ini adalah berupa modul akuntansi yang menarik, efisien dan efektif. Sebelum menilai kemenarikan, keefisienan dan keefektifan E-modul maka dilakukan validasi ahli terlebih dahulu. Validasi ahli dilakukan untuk mengetahui kelayakan E-modul untuk digunakan dalam kegiatan pembelajaran. Validasi ahli dalam meliputi validasi ahli isi/materi, validasi ahli bahasa dan validasi ahli desain.

Berdasarkan kegiatan validasi yang dilakukan oleh peneliti, maka diperoleh skor validasi isi/materi tahap I sebesar 78,4\%. Hasil tersebut menunjukkan bahwa modul akuntansi sudah layak digunakan namun perlu dilakukan beberapa revisi. Terdapat 3 komponen yang harus direvisi pada validasi isi/ materi yaitu perubahan urutan metode pencatatan persediaan barang dagangan, pengurangan jumlah perintah yang diminta pada penilaian portofolio, dan perbaikan pada materi infografis disesuaikan dengan akuntansi persediaan barang dagangan. Hasil rata-rata skor validasi isi/materi tahap II sebesar 95,5\%.

Validasi desain modul tahap I diperoleh skor sebesar 77,3\%. Hasil yang diperoleh menunjukkan bahwa modul akuntansi sudah layak namun terdapat beberapa komponen yang perlu diperbaiki, yaitu penyajian gambar, warna tulisan, penambahan informasi pada sampul depan, penambahan infografis, serta pembenahan 
pada seluruh kata yang menggunakan shape miring. Selanjutnya dilakukan validasi desain tahap II diperoleh masing-masing skor sebesar $92,1 \%$.

Validasi bahasa tahap I diperoleh skor sebesar 78,4\%. Terdapat 3 hal yang perlu diperbaiki dalam segi bahasa sesuai dengan masukan dari validator bahasa, yaitu konsistensi penggunaan kata/ kalimat, penggunaan kalimat efektif dan perbaikan pada kalimat yang ambigu atau memiliki banyak makna. Selanjutnya validasi bahasa tahap II diperoleh nilai sebesar $95,5 \%$.

Pada tahap II masing-masing validasi telah memperoleh hasil yang menunjukkan bahwa modul sudah layak untuk diujicobakan dan tidak perlu adanya revisi, maka modul akuntansi dapat diujicobakan pada kelompok kecil dan kelompok besar. Berikut ini uraian dari hasil uji coba kelompok kecil dan kelompok besar yang dilihat dari kemenarikan, keefisienan dan keefektifan modul:

\section{1) Hasil Uji Tingkat Daya Tarik Modul Akuntansi}

Tingkat daya tarik modul akuntansi pada uji coba kelompok kecil diukur berdasarkan hasil angket respon siswa yang diisi oleh 12 siswa dari kelas XI Akuntansi 1. Pengisisan angket respon siswa dilakukan setelah siswa menggunakan modul akuntansi yang dikembangkan oleh peneliti. Rata-rata persentase skor per indikator dan skor per aspek yang diperoleh dari uji kelompok kecil ini masing-masing adalah sebesar $86 \%$ dengan kategori menarik sekali, sehingga modul akuntansi yang dikembangkan tidak perlu adanya proses revisi ulang setelah uji kelompok kecil.

Selanjutnya pengukuran tingkat kemenarikan modul akuntansi dilakukan pada uji coba kelompok besar yang melibatkan seluruh siswa kelas XI Akuntansi 3 di SMK Negeri 1 Jember yang berjumlah 38 siswa dengan menggunakan angket respon siswa. Pengisian angket dilakukan setelah siswa menggunakan modul akuntansi yang dikembangkan. Rata-rata persentase perolehan skor respon siswa terhadap modul adalah sebesar $91 \%$ dengan kategori menarik sekali.

\section{2) Hasil Uji Efisiensi Modul Akuntansi}

Efisiensi penggunaan modul dapat dilihat dari penggunaan waktu yang digunakan oleh guru untuk menyampaikan KD persediaan barang dagang lebih cepat daripada alokasi waktu yang telah tersedia pada silabus. Waktu yang tersedia untuk KD persediaan barang dagangan yaitu 4 x $3 \mathrm{JP}$, dimana setiap satu jam pelajaran adalah 45 menit. Hasil uji coba penggunaan modul dalam pembelajaran KD persediaan barang dagangan hanya membutuhkan waktu 3 x 3 JP, baik pada uji kelompok kecil maupun besar. Sisa waktu 1 x 3 JP dapat digunakan oleh guru untuk melakukan pengayaan maupun penambahan latihan soal. Hal tersebut didukung oleh hasil wawancara dengan guru pengampu mata pelajaran akuntansi keuangan dan perwakilan siswa pada uji kelompok kecil maupun besar.

Hasil uji coba dan wawancara dengan guru dan perwakilan siswa tersebut dapat disimpulkan bahwa modul akuntansi keuangan KD persediaan barang dagang dapat membantu siswa lebih cepat memahami materi dengan baik, sehingga dapat dikatakan bahwa modul akuntansi yang dikembangkan dikatakan efisien. Salah satu fungsi modul adalah menghemat waktu pendidik dalam mengajar. Jadi modul akuntansi merupakan bahan ajar yang efisien, seperti yang diungkapkan oleh guru yaitu:

"KD persediaan barang dagangan itu terdiri dari banyak metode, perkiraan saya akan menambah alokasi waktu lebih dari yang ditentukan pada silabus. Namun pada faktanya, pembelajaran lebih singkat dengan menggunakan modul daripada menggunakan bahan ajar sebelumnya berupa buku paket akuntansi. Alokasi waktu pada silabus untuk KD persediaan barang dagang yaitu 4x3JP, namun pada penerapannya hanya membutuhkan waktu 3x3JP siswa sudah memahami dan mampu mengerjakan latihan soal yang ada di modul dengan baik.”. (B, 45th)

Berdasarkan hasil wawancara dengan guru mata pelajaran akuntansi keuangan dapat disimpulkan bahwa modul akuntansi yang dikembangkan dapat dikatakan efisien untuk digunakan dalam proses pembelajaran dengan melihat alokasi waktu yang dibutuhkan kurang dari alokasi waktu yang terdapat pada silabus. Alokasi waktu yang dibutuhkan hanya 3 x 3 JP sedangkan alokasi yang terdapat pada silabus 4 x 4 JP.

\section{3) Hasil Uji Efektivitas Modul Akuntansi}

Tingkat efektivitas modul akuntansi yang dikembangkan diketahui melalui perbandingan nilai pretest sebelum menggunakan modul akuntansi dan nilai posttest sesudah menggunakan modul akuntansi pada KD persediaan barang dagangan. Nilai yang dibandingkan pada uji kelompok kecil yaitu nilai pretest dan posttest yang diperoleh oleh 12 siswa kelas XI Akuntansi 1 yang telah dipilih dengan kemampuan akademik tinggi, sedang, dan rendah. Berikut adalah distribusi nilai pretest dan posttest menggunakan modul akuntansi pada uji kelompok kecil: 


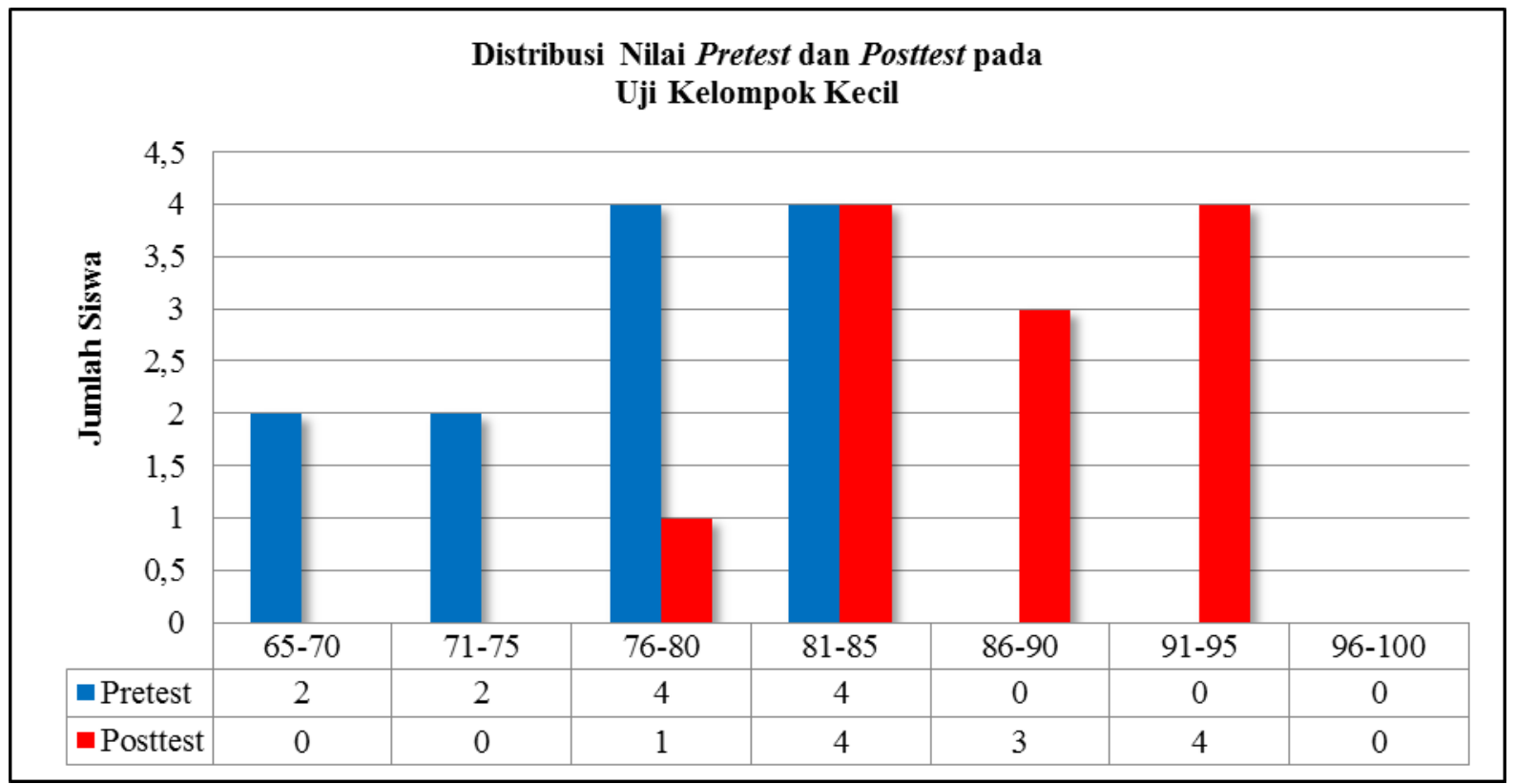

Gambar 1. Distribusi Nilai Pretest dan Posttest padaUji Kelompok Kecil

Pada uji beda dengan menggunakan bantuan program SPPS versi 22 diketahui tingkat efektivitas modul akuntansi yang ditunjukkan dengan tabel berikut:

Tabel 1. Hasil Statistik dengan Sampel Berpasangan pada Uji Kelompok Kecil

Paired Samples Statistics

\begin{tabular}{|ll|r|r|r|c|}
\hline & \multicolumn{1}{|c|}{ Mean } & N & Std. Deviation & Std. Error Mean \\
\hline Pair 1 & Pretest & 76,83 & 12 & 4,914 & 1,419 \\
& Posttest & 85,17 & 12 & 5,589 & 1,614 \\
\hline
\end{tabular}

Sumber: Hasil Uji Beda SPSS versi 22

Rata-rata nilai pretest sebelum menggunakan modul yaitu sebesar 76,83 dengan simpangan baku 4,914. Berbeda dengan rata-rata nilai posttest setelah penggunaan modul sebesar 85,17 dengan simpangan baku 5,589. Berdasarkan keterangan pada tabel diketahui bahwa terdapat peningkatan rata-rata hasil belajar siswa sebelum dan sesudah menggunakan modul akuntansi.

Adapun hasil korelasi antara nilai sebelum dan sesudah menggunakan modul akuntansi pada uji kelompok kecil dapat dilihat pada tabel berikut :

Tabel 2. Korelasi Sampel Berpasangan pada Uji Kelompok Kecil

Paired Samples Correlations

\begin{tabular}{|ll|r|r|r|}
\hline & & N & Correlation & \multicolumn{1}{|c|}{ Sig. } \\
\hline Pair 1 & $\begin{array}{l}\text { Pretest } \\
\text { Posttest }\end{array}$ & 12 &, 901 &, 000 \\
\hline
\end{tabular}

Sumber: Hasil Uji Beda SPSS versi 22

Tabel di atas menunjukkan bahwa hubungan antara nilai hasil belajar siswa sebelum dan sesudah menggunakan modul akuntansi pada uji kelompok kecil ini sangat kuat ditunjukkan dengan angka korelasi 0,901 dan angka probabilitas $0,000<0,050$.

Hasil t-tes dengan sampel berpasangan pada ujicoba terbatas yang melibatkan 12 siswa kelas XI Akuntansi 1 disajikan pada tabel di bawah ini: 
Tabel 3. Hasil T-Test Sampel Berpasangan pada Uji Kelompok Kecil

Paired Samples Test

\begin{tabular}{|c|c|c|c|c|c|c|c|c|}
\hline & \multicolumn{5}{|c|}{ Paired Differences } & \multirow{3}{*}{$\mathrm{t}$} & \multirow{3}{*}{$\mathrm{df}$} & \multirow{3}{*}{ Sig. (2-tailed) } \\
\hline & \multirow[t]{2}{*}{ Mean } & \multirow[t]{2}{*}{$\begin{array}{c}\text { Std. } \\
\text { Deviation }\end{array}$} & \multirow{2}{*}{$\begin{array}{l}\text { Std. } \\
\text { Error } \\
\text { Mean }\end{array}$} & \multicolumn{2}{|c|}{$\begin{array}{l}95 \% \text { Confidence } \\
\text { Interval of the } \\
\text { Difference }\end{array}$} & & & \\
\hline & & & & Lower & Upper & & & \\
\hline $\begin{array}{ll}\text { Pair 1 } & \text { Pretest - } \\
\text { Posttest }\end{array}$ & $-8,333$ & 2,425 & ,700 & $-9,874$ & $-6,793$ & $-11,906$ & 11 & ,000 \\
\hline
\end{tabular}

Sumber: Hasil Uji Beda SPSS versi 22

Berdasarkan tabel 4.9 dapat disimpulkan bahwa terdapat perbedaan yang signifikan pada nilai sebelum dan sesudah menggunakan modul akuntansi. Dibuktikan dengan hasil dari $t_{\text {hitung }}=11,906 \geq \mathrm{t}_{0,05 ; 11}=2.200$ atau dapat dilihat dari nilai signifikansi $=0,000<\alpha=0,050$. Mean sebesar $-8,333$ menunjukkan bahwa nilai haisl belajar siswa sebelum menggunakan modul lebih rendah dibandingkan dengan sesudah menggunakan modul.

Pada uji kelompok besar, tingkat efektivitas modul akuntansi diketahui melalui perbandingan nilai pretest dan posttest siswa XI Akuntansi 3 pada KD persediaan barang dagangan. Berikut adalah distribusi nilai hasil belajar siswa XI Akuntansi 3 sebelum dan sesudah menggunakan modul akuntansi pada gambar berikut:

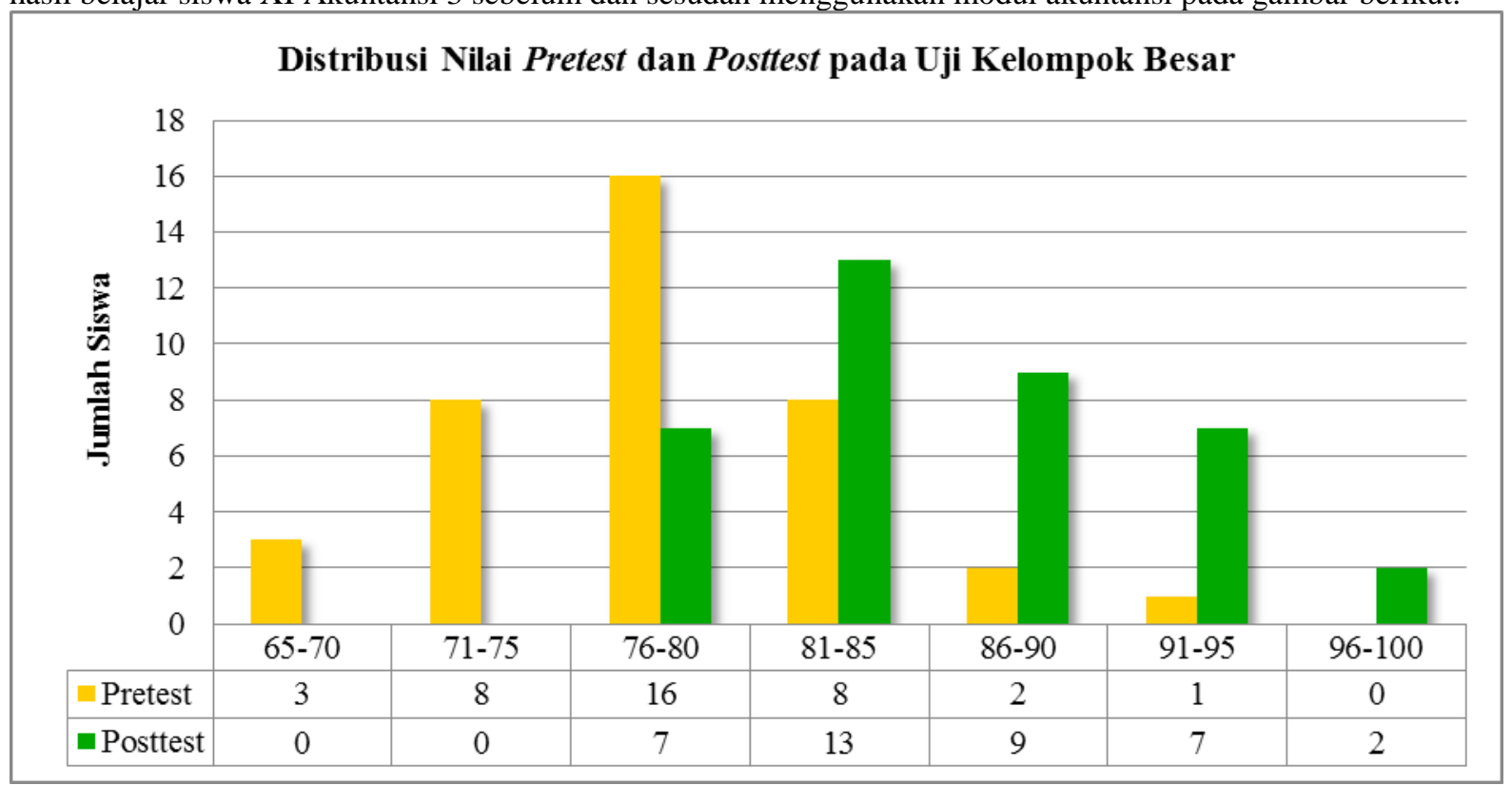

Gambar 2. Distribusi Nilai Pretest dan Posttest pada Uji Kelompok Besar

Pada gambar tersebut diketahui terdapat peningkatan nilai hasil belajar siswa pada sebelum dan setelah menggunakan modul akuntansi yang dikembangkan. Hal tersebut menunjukkan bahwa modul akuntansi keuangan KD pesediaan barang dagangan yang dikembangkan dapat meningkatkan hasil belajar siswa.

Uji beda diperoleh dengan bantuan program SPPS versi 22, diketahui tingkat efektivitas modul akuntansi yang ditunjukkan dengan tabel berikut:

Tabel 4. Hasil Statistik dengan Sampel Berpasangan pada Uji Kelompok Besar

Paired Samples Statistics

\begin{tabular}{|ll|r|r|r|r|}
\hline & & \multicolumn{1}{|c|}{ Std. } & \multicolumn{2}{|c|}{ Std. Error Mean } \\
\hline Pair 1 & Pretest & 75,71 & 38 & 5,114 &, 830 \\
& Posttest & 85,13 & 38 & 5,458 &, 885 \\
\hline
\end{tabular}

Sumber: Hasil Uji Beda SPSS versi 22

Berdasarkan tabel di atas menunjukkan bahwa rata-rata nilai ulangan harian hasil belajar siswa sebelum 
menggunakan modul yaitu sebesar 75,71 dengan simpangan baku 5,114. Perbedaan terlihat pada rata-rata nilai hasil belajar siswa setelah penggunaan modul sebesar 85,13 dengan simpangan baku 5,458. Diketahui keterangan pada tabel bahwa terdapat peningkatan rata-rata hasil belajar siswa kelas XI Akuntansi 3 sebelum dan sesudah menggunakan modul akuntansi. Simpangan baku menunjukkan antara jarak teratas dan terbawah dari nilai rata-rata hasil belajar siswa yang semakin kecil maka dapat diartikan bahwa jarak nilai terendah siswa semakin mendekati nilai tertinggi siswa.

Adapun hasil korelasi antara nilai hasil belajar siswa sebelum dan sesudah menggunakan modul akuntansi pada uji kelompok besar dapat dilihat pada tabel berikut:

Tabel 5. Korelasi Sampel Berpasangan pada Uji Kelompok Besar Paired Samples Correlations

\begin{tabular}{|ll|r|r|r|}
\hline & N & Correlation & \multicolumn{1}{|c|}{ Sig. } \\
\hline Pair 1 & Pretest \& Posttest & 38 &, 843 &, 000 \\
\hline
\end{tabular}

Sumber: Hasil Uji Beda SPSS versi 22

Tabel di atas menunjukkan bahwa hubungan antara nilai hasil belajar siswa sebelum dan sesudah menggunakan modul akuntansi pada uji kelompok besar ini sangat kuat ditunjukkan dengan angka korelasi 0,843 dan angka probabilitas $0,000<0,050$.

Hasil t-tes dengan sampel berpasangan pada uji coba kelompok besar yang dilakukan pada kelas XI Akuntansi 3 disajikan pada tabel di bawah ini.

Tabel 6. Hasil T-Test Sampel Berpasangan pada Uji Kelompok Besar

Paired Samples Test

\begin{tabular}{|c|c|c|c|c|c|c|c|c|}
\hline & \multicolumn{5}{|c|}{ Paired Differences } & \multirow{3}{*}{$\mathrm{T}$} & \multirow{3}{*}{ df } & \multirow{3}{*}{$\begin{array}{l}\text { Sig. (2- } \\
\text { tailed) }\end{array}$} \\
\hline & \multirow[t]{2}{*}{ Mean } & \multirow{2}{*}{$\begin{array}{l}\text { Std. } \\
\text { Deviatio } \\
\mathrm{n}\end{array}$} & \multirow[t]{2}{*}{$\begin{array}{l}\text { Std. } \\
\text { Error } \\
\text { Mean }\end{array}$} & \multicolumn{2}{|c|}{$\begin{array}{l}\text { 95\% Confidence } \\
\text { Interval of the } \\
\text { Difference }\end{array}$} & & & \\
\hline & & & & Lower & Upper & & & \\
\hline $\begin{array}{ll}\text { Pair } 1 & \text { Pretest - } \\
& \text { Posttest }\end{array}$ & $-8,421$ & 2,983 & ,484 & $-9,402$ & $-7,441$ & $-17,402$ & 37 & ,000 \\
\hline
\end{tabular}

Sumber: Hasil Uji Beda SPSS versi 22

Berdasarkan tabel tersebut disimpulkan bahwa terdapat perbedaan yang signifikan antara nilai hasil belajar siswa sebelum dan sesudah menggunakan modul akuntansi pada uji kelompok besar di XI Akuntansi 3. Perbedaan yang signifikan ditunjukkan dengan hasil dari $t_{\text {hitung }}=17,402 \geq \mathrm{t}_{0,05 ; 37}=2.026$ atau dapat dilihat dari nilai signifikansi $=0,000<\alpha=0,050$. Mean sebesar $-8,421$ menunjukkan bahwa nilai pretest sebelum menggunakan modul lebih rendah dibandingkan dengan nilai posttest sesudah menggunakan modul.

Modul akan efektif membuat peserta didik menguasai kompetensi yang telah ditetapkan apabila sumber belajar yang digunakan mudah pengadaan maupun pengoperasiannya [4]. Maka modul akuntansi yang dihasilkan merupakan modul yang efektif untuk digunakan pada pelajaran akuntansi keuangan KD persediaan barang dagangan. Oleh karena itu dapat disimpulkan bahwa efektivitas adalah keberhasilan siswa untuk mencapai tujuan pembelajaran yang telah ditetapkan melalui pemanfaatan sumber daya, sarana dan prasarana dalam jumlah tertentu yang secara sadar ditetapkan sebelumnya.

\section{KAJIAN DAN SARAN}

Produk yang dikembangkan berupa modul akuntansi pada KD persediaan barang dagangan yang telah melewati beberapa tahap validasi, uji coba, dan beberapa kali revisi selanjutnya telah menjadi produk final yang menarik, efisien dan efektif. Modul Akuntansi Kompetensi Dasar (KD) persediaan barang dagangan yang digunakan untuk siswa kelas XI Akuntansi di SMK Negeri 1 Jember yang terdiri dari 3 bagian utama.

a. Bagian Pertama, bagian ini terdiri dari halaman sampul, kata pengantar, daftar isi, glosarium, dan peta konsep.

b. Bagian kedua, yaitu bab pendahuluan yang terdiri dari (1) Kompetensi Dasar (KD) yang dipelajari yaitu persediaan barang dagangan baik secara periodik maupun perpetual. (2) Deskripsi yang berisi tentang penjelasan singkat tentang materi yang disajikan dalam modul. (3) Waktu berisi penggunaan waktu dalam menggunakan modul untuk mengguasai materi. (4) Prasyarat berisi kemampuan awal yang harus dikuasai 
siswa sebelum menggunakan modul. (5) Petunjuk penggunaan modul berisi panduan bagi siswa dan guru dalam menggunakan modul. (6) Tujuan akhir berisi tujuan pembelajaran yang akan dicapai dalam KD persediaan barang dagangan.(7) Cek kemampuan berisi tentang kriteria keberhasilan siswa dalam mempelajari modul.

c. Bagian ketiga, yaitu bab kegiatan pembelajaran I yang terdiri dari uraian materi pencatatan persediaan barang dagangan secara periodik, rangkuman materi, dan penugasan berupa tes formatif dengan jawaban essay, tugas kelompok, latihan soal praktik, dan penilaian portofolio. Selanjutnya, bagian keempat yaitu bab kegiatan pembelajaran II yang isinya sama dengan bagian 3 namun dengan pembahasan yang berbeda, yaitu materi pencatatan persediaan secara perpetual. Modul ini pada bagian akhir juga dilengkapi dengan kunci jawaban dan daftar pustaka yang dapat membantu siswa untuk melacak sumber referensi yang digunakan agar memperoleh informasi lebih lanjut.

Adapun kelebihan modul akuntansi KD persediaan barang dagangan, yaitu:

a. Modul disusun sesuai dengan kebutuhan dan karakteristik siswa kelas XI Akuntansi di SMK Negeri 1 Jember dengan materi yang disajikan secara lengkap, sistematis dan penjelasan menggunakan contoh sehingga dapat mempermudah siswa dalam memahami isi modul dengan baik dan mencapai tujuan pembelajaran yang diharapkan.

b. Kolom catatan, yaitu modul ini dilengkapi dengan kolom catatan yang memungkinkan siswa tidak membutuhkan buku catatan lagi dan terdapat pertanyaan-pertanyaan yang dapat mengkonstruk pemahaman yang dimiliki siswa.

c. Desain, yaitu modul yang dikembangkan ini disajikan dengan lembar sampul dan lembar isi yang menggunakan layout yang bervariasi dan berwarna, serta penggunaan gambar yang berkaitan dengan materi.

d. Tersedia LKS (Lembar Kerja Siswa) yang berisi lembar jawaban atas latihan soal-soal sehingga sesuai dengan pembelajaran akuntansi yang aplikatif.

e. Penilaian Portofolio, berisi tugas dan lembaran yang nantinya digunakan sebagai lembar hasil penugasan siswa sehingga memudahkan guru dalam memberikan penilaian secara kognitif, afektif, dan psikomotor siswa sesuai dengan penerapan Kurikulum 2013.

f. Infografis, terdapat beberapa informasi seputar akuntansi persediaan barang dagangan yang disajikan dalam modul yang dapat menambah wawasan siswa.

Adapun kelemahan dari modul akuntansi yang telah dikembangkan antara lain, (1) modul ini hanya terbatas pada mata pelajaran akuntansi keuangan KD persediaan barang dagangan yang digunakan untuk siswa kelas XI Akuntansi di SMK Negeri 1 Jember dan (2) modul akuntansi disajikan dalam bentuk cetak sehingga membutuhkan biaya percetakan.

Berdasarkan kesimpulan yang telah didapat dari penelitian ini, maka dapat dikemukakan beberapa saran sebagai berikut.

1. Saran Pemanfaatan Modul Akuntansi

Produk yang dihasilkan dalam penelitian pengembangan ini berupa modul akuntansi keuangan KD persediaan barang dagangan yang berbentuk cetak, sehingga siswa dan guru sebagai pengguna dapat digunakan langsung tanpa dengan bantuan modul lain. Modul ini bersifat lebih konkret, siswa dapat lebih mudah dalam mempelajari isi modul dan mengerjakan latihan soal yang diberikan. Modul ini diharapkan menjadi bahan ajar yang wajib dimiliki siswa, sehingga siswa dapat memanfaatkan secara maksimal.

2. Saran Perluasan Modul Akuntansi

Peneliti juga menyarankan agar modul yang telah berhasil dikembangkan ini dapat digunakan juga di sekolah menengah atas lainnya pada materi yang sama pula. Ada baiknya, jika rencana pemanfaatan lebih luas terhadap modul ini disosialisasikan terlebih dahulu kepada pihak terkait seperti Tim MGMP (Musyawarah Guru Mata Pelajaran) dan sekolah-sekolah terkait.

3. Saran Pengembangan Modul Akuntansi

Peneliti menyarankan adanya perluasan subjek ujicoba dalam penelitian, tidak hanya sebatas beberapa kelas dalam satu sekolah saja. Perluasan materi tidak hanya sebatas KD persediaan barang dagangan, namun dapat dikembangkan menjadi seluruh KD dalam satu semester sehingga menjadi modul yang lengkap dan dapat digunakan pada proses pembelajaran Akuntansi Keuangan dalam satu semester.

\section{DAFTAR PUSTAKA}

Daryanto. 2013. Menyusun Modul (Bahan Ajar untuk Persiapan Guru dalam Mengajar). Yogyakarta: Gava Modul.

Muhafid, E. A. 2013. Pengembangan Modul IPA Terpadu Berpendekatan Keterampilan Proses Pada Tema Bunyi di SMP Kelas VII. Unnes Science Education Journal 2(1): 1-15. 
Prastowo, A. (2015). Panduan Kreatif Membuat Bahan Ajar Inovatif. Jogjakarta: DIVA Press.

Slameto. 2015. Belajar dan Faktor-Faktor yang Mempengaruhi. Jakarta: Rineka Cipta

Thiagarajan, S., Semmel, D. S, \& Semmel, M. I. 1974. Instructional Developmentfor Training Teachers of Expectional Children. Minneapolis: Leadership Training Institute.

Uno, Hamzah B. 2008. Model Pembelajaran. Jakarta: PT. Bumi Aksara. 